Milan Počuča', Rajko Tepavac ${ }^{2}$, Jana Cvijić $^{3}$, Aleksandra Mitrović ${ }^{4}$

${ }^{1}$ University Business Academy in Novi Sad, Faculty of Law

2 University Business Academy in Novi Sad, Faculty of Economy and Engineering management

${ }^{3}$ Belgrade Business School

${ }^{4}$ University of Kragujevac, Faculty of Hotel Management and Tourism

\title{
Potential Sources for Financing Environmental Protection Projects - Focusing on Energy Efficiency
}

UDC: 005.8:[502.171:620.92(497.11) 005.35:336.581

DOI: 10.7595/management.fon.2015.0014

\begin{abstract}
This paper elaborates financial mechanisms for financing energy efficiency with particular emphasis on the resources from financial institutions and equity funds and capital from the companies themselves.

By conducting relevant academic research of literature and data from print and electronic sources (statistical reports, laws and regulations, statements of companies and financial institutions), as well as from the practical experience of some countries, it has been observed that the poor representation of adapted financial mechanisms is a major constraint to the emergence of a culture of energy efficiency in most countries, including Serbia. Even where they exist they are not necessarily known to make use of successful experiences. By conducting an analysis of the relevant academic literature and an analysis of practical experiences in the domain of energy efficiency and renewable energy sources it was concluded that energy efficiency is a significant potential for growth of the economic strength of Serbia, and therefore incentives should influence a greater use of renewable energy and a reduction in use of the fossil fuels as an energy source.
\end{abstract}

Keywords: environment, energy efficiency, financing, financial mechanisms, socially-responsible behaviour

\section{Introduction}

The economic growth of a country depends, among other things, on available energy sources. Forms of economic growth, in line with this, are oriented towards the protection of the environment through the use of renewable energy, and various forms of sustainable investments (Knežević, Marković \& Stanković, 2013). Energy costs represent an important item in the structure of total costs, and any change in energy prices significantly affects cost efficiency as well as formation of selling prices of different products and services.

Energy efficiency means a rational use of energy which includes a set of activities that enable optimal energy production and consumption: reduction of energy loss, selection of alternative and clean energy sources, use of efficient technologies, defining standards of energy consumption and so on. Energy efficiency can be achieved in any sector that requires energy consumption: industry, transport, households and services, etc. Finally, energy efficiency is a way of managing the growth in energy consumption.

According to the perspectives of the International Energy Agency (IEA), the energy needs of the planet in 2030 will be increased by almost $60 \%$ relative to the current needs, and fossile fuels will remain the most widely used energy source. Predictions are that the level of annual growth in energy demand will slightly drop as well as energy power, and that the economic and demographic growth connected to increased urbanization will lead to an increase in demand of about $1.7 \%$ annually over the next 25 years, unless there is a significant progress in the field of energy efficiency measurement (Energy Information Administration, 2006).

The entry strategy for financing ecological projects, including the energy efficiency projects at the international market is quite extensive. It sets financial goals, sources and a direction of international undertakings of the companies in the next period, for the period long enough to achieve sustainable development at the 
international market. As financing sources, it includes structural funds (The Climate Investment Funds, 2015), research programmes, EAFRD, CIP, LIFE+ and others.

Managing and reporting on environmental performance can lead to significant business benefits as well as benefits for the environment (Petrović, Slović \& Ćirović, 2012). IEA analyses and reports (Energy Information Administration, 2006) show it is possible to cut global energy demand by $10 \%$ by the year 2030 , as well as reduce the industrial emissions of greenhouse gases by $16 \%$, primarily by redirecting investments for energy production towards introduction of projects that replace inefficient equipment with the technology that saves energy. Existing technologies should enable reducing the energy consumption in current industrial installations by half, and up to $90 \%$ in those in new factories (International Energy Agency, 2006).

Developing countries in particular need financing and provision of projects in the field of energy efficiency improvement. However, commercial investors are reluctant to take a first step and take such risk. To improve this situation, public-private partnership mechanism suggests an instrument that offers subsidies that enable coverage of a part of development costs. If they join their efforts, public and private sector can have an irreplaceable role and find the needed solutions for challenges that are imposed in the area of environmental protection. This partnership would be beneficial for all (Barbut, 2010). Its aim is to stimulate the research into innovative technological and financial solutions to the key problems in the field of energy efficiency. Barbut recommends the advantages of the application of public-private partnership in financing the energy efficiency projects, among others, the following:

- reduction of ecological risks for the observed enterprise;

- better positioning of an observed enterprise in the innovation and development market;

- the observed enterprise should become recognizable as a partner and an investor regarding environmental solutions.

The experience of European countries shows that various fiscal sources can be used for adequate environmental protection, such as certain types of taxes and duties. Apart from these, in most of the countries in which transition process was completed successfully, the participation of income from privatisation in financing eco funds is very important, before all for solving inherited problems in the form of developed, historic pollution.

Financial programmes and institutions that are of special importance for financing ecological projects, including energy efficiency projects and the use of renewable sources, are the following (Knežević, Joksimović \& Bilić, 2012):

- "The social development bank in Europe (CEB Bank);

- EIB European Investment Bank (the EU bank);

- IBRD - International Bank for Reconstruction and Development (with the World Bank);

- IPA - Instrument for Pre-Accession Assistance (an aid programme available also to the Republic of Serbia since 2008);

- CFU - The Carbon Finance Unit (with the World Bank): Prototype Carbon Fund; Prototype Carbon Fund, Community Development Carbon Fund, Italian Carbon Fund, The Netherlands CDM Facility, and other;

- CFE - Carbon Fund for Europe;

- UNDP - United Nations Development Programme;

- The - Climate Investment Funds;

- GEF - Global Environment Facility;

- GGF - Green for Growth Fund Southeast Europe:

- LIFE+ - The Financial Instrument for the Environment;

- EBRD - European Bank for Reconstruction and Development; etc".

The characteristic of IPA funds (Instrument for Pre-Accession Assistance) (The Agency for Regional Development, Croatia \& The Delegation of the European Union to the Republic of Serbia, 2007) is that they give grants. They are a kind of assets in addition to resources already earmarked for reforms from the budget of developing countries. These assets can be used for different types of investment projects - equipment procurement, execution of works, implementation of financial arrangements with other financial institutions. 


\section{Materials and Methods}

The desk research method, description, and a method of generalization respecting the facts and opinions relevant to the academic and experiential level in the respective areas are applied in this paper. The research framework itself will comprise collecting data and information from primary and secondary sources. Description will be used as a general scientific research method by which the modalities of financing energy efficiency will be described in general and systematically, and along this will be given a summary of the current legislation governing the research subject in this paper. Description will create an introduction to analysis of possible strategies of financing energy efficiency and renewable energy sources on the basis of the previous analysis of the experiences of other countries, observed on international and regional levels.

\section{Results and Discussion}

\subsection{Financing Energy Efficiency Projects in the World}

Knežević et al. (2012, p. 150) point out that the structure of the planet's ecosystem in the second half of the 20th century underwent a transformation faster than in any other epoch in the history, that we are confronted with enormous environmental challenges around the world, particularly in the field of obtaining energy resources and that the world economy is dependent on fossil fuels to a large extent (WCED, 1987).

Energy management has become a central social, economical and political issue of each country. Traditional energy sources, oil predominantly, are limited, and the irrational use and profit-only orientation have led to chronic disorders in the area of efficient management of energy potentials.

The International Finance Corporation (IFC) was established in 1956, as an affiliate of the World Bank, with the aim to promote economic development by stimulating the growth of private companies in member countries, especially in underdeveloped areas, thus supplementing activities of the International Bank for Reconstruction and Development (IBRD). The IFC only invests in projects that generate profit from their own funds, by syndicating or investing in the ownership structure of non-voting private companies (International Finance Corporation, 2015).

The World Bank green bonds are used for raising funds from investors who expect a fixed return on their investment, which would serve as a support to the World Bank to grant loans to eligible projects (Chiginsky, 2010) of the bank aimed at mitigating climate changes or at helping vulnerable people to adapt to such changes. Since 2008, the World Bank has issued green bonds worth over 2 billion US dollars [(The World Bank, 2009; 2011; 2014)]. The European Investment Bank (EIB) and the German Development Bank - KfW (KfW Bankengruppe) in cooperation with several other institutions have established a fund for the promotion of energy efficiency and renewable energy projects in South-East Europe and Turkey called SE4F Fund (Kreiß \& Roos, 2009). The aim is to assist public and private companies and households to invest in the field of energy efficiency and renewable energy, thus facilitating Europe to achieve projected climate goals. The Fund was established as a public-private partnership that provides support to commercial private investors through public funds (EBRD, 2009).

The GGF (Green for Growth Fund) is a public-private partnership with an investor base comprised of donor agencies, international financial institutions and institutional private investors (Green for Growth Fund, 2015). The Green for Growth Fund was founded in a similar way, for the purpose of cutting energy consumption and $\mathrm{CO}_{2}$ emission by minimum $20 \%$ and to that end:

- Provides funds to the financial sector for the purpose of financing energy efficiency projects in the segment of SMEs and retail;

- Directly finances projects on renewable energy sources, companies providing energy services, companies providing services or manufacturing energy efficient equipment.

The intensification of crediting eco-industry can provide new jobs. In that sense, there may be arrangements between EBRD and national banks in respect of lending to projects in the field of energy efficiency and the use of renewable energy sources. Coretchi (2009) points out that "the EBRD is increasing its commitment to energy efficiency projects with a €25 million investment in the newly established Southeast Europe Energy Efficiency Fund (SE4F)". 
It is important to mention a direct EBRD financing of energy efficiency projects in the industry as well as renewable energy sources projects. It is a WeBSEDFF (Western Balkans Sustainable Energy Direct) which is an EBRD line for direct financing of projects in the field of sustainable energy development for two purposes 1) energy efficiency projects in the industry and 2) renewable energy sources projects (WeBSEDFF, 2015). This line is designed for all countries of the Western Balkans, with a focus on small and mediumsized enterprises that have a dominant private ownership in total capital. The WeBSEDFF operates in Bosnia and Herzegovina, Croatia, FYR Macedonia, Montenegro, Serbia and Albania. Types of projects such as renewable energy sources (run'of'river power plants, wind-generators, solar systems, hydro power plants) and industrial energy efficiency (cogeneration, trigeneration, boilers modernisation, used waste heat from technological processes and so on) can be financed through the WeBSEDFF.

The Prototype Carbon Fund mobilises sources from public and private sectors to fund projects that support the reduction of the greenhouse gas emission. Carbon credit is equivalent to one tonne of carbon dioxide whether removed, avoided or seized (Kelly \& Jordan, 2004). Carbon market is divided into voluntary and regulatory (Carbon Markets, 2010). The concept of selling and buying carbon credits at specialised markets was introduced, such as the Carbon Trade Exchange. There is a huge number of companies that sell carbon credits to commercial and individual customers in order to reduce their imprint on greenhouse gas emissions on voluntary basis. The credit is bought through an investment fund or companies that have built up credits through their own projects.

The Royal Bank of Scotland (RBS) is one of the biggest investors of renewable energy sources in the world. the Bank has become a successful provider of Renewable Energy Grants for renewable energy projects in both the UK and the US.

The policy of the European Union underlines the importance of applying the PPP in sectors such as environment, energy, transportation and health care. Knežević, Marković \& Počuča (2012, p. 167.) point out that "it is important to identify the true measure of the relationship between public and private capital and increase transparency in decision making".

\subsection{Level and State of Environmental Protection in Serbia}

The long-term strategy of the Republic of Serbia in the field of environmental protection implies integration of environmental protection policy into all other sectors' policies, acceptance of greater individual responsibility for the environment as well as an increased and more active participation of the public in the decision making processes related to the environmental protection [(Official Gazette of the Republic of Serbia, No. 80/11, 2011; No.12, 2010)]. The waste management system should be further developed and investment projects related to construction of waste management infrastructure should be favoured (Petrović, Išljamović \& Jeremić, 2010).

Primary energy reserves in Serbia (coal, oil, hydro potential, gas) are meagre, but also are an important potential for the energy sector development. In addition to that, Serbia is relatively rich in hydro energy, but such energy is insufficiently used. Serbia has a significant potential to increase the energy efficiency, but due to the lack of extensive study, it is impossible to point out the quantitative parameters in the segment of potential energy savings and increase in cost efficiency (Jednak, Kragulj, Bulajić \& Pittman, 2009). The Energy Efficiency Agency of the Republic of Serbia was formed for the strategic purposes of improvement of the energy management quality in respect of more rational use of energy and energy sources.

In Serbia there are the following potential sources of financing [(Official Gazette of the Republic of Serbia, No. 135/2004, 36/2009, 36/2009 - other law, 72/2009 - other law and 43/2011 - decision US; No. 12, 2010)]:

- Application of the Polluter Pays Principle;

- Fee for use of natural resources;

- Fee for environmental pollution;

- Fines for non-compliance with environmental standards;

- Fees of local government units;

- Subsidies;

- Tax incentives exemption from payment of fees. 
The Polluter Pays Principle means that the polluter under the law bears the total expenses incurred due to environmental impairment that include the expenses of environmental risk and the expenses of removal of environmental damage. Environmental taxes should above all serve more as an incentive than a penalty in the sense that polluters are free to decide whether to avoid payment of taxes or to have additional expenses (Official Gazette of the Republic of Serbia, No. 135/2004, 36/2009, 36/2009 - other law, 72/2009 - other law and 43/2011 - decision US).

The role of the National Register of the Sources of Pollutants is especially important since, in order to invest in environmental protection, it is necessary first to identify the current pollutants, potential pollutants and then to identify the financing strategy.

The sources of financing environmental projects include the earmarked funds of the budgets of the Republic and municipal budgets, their own funds based on the economic instruments, the loans of the Republic and of municipalities, as well as international resources which are primarily related to donations, loans and credits.

The Public-Private Partnership Law opens new possibilities for public-private partnerships, particularly for defining the long-term partnership relation of the public and private partnerships (Official Gazette of the Republic of Serbia, No. 88,2011 ) which is also a great opportunity to promote products aimed at improving of energy efficiency.

The documents "The National Environmental Protection Programme" (Official Gazette of the Republic of Serbia, No .12, 2010) and "The National Environmental Approximation Strategy of the Republic of Serbia" (Official Gazette of the Republic of Serbia, No. 80/11, 2011) refer to the overall financing of environment, environmental fees, i.e., the funds required for the implementation of these two documents. To obtain transparency in respect of investment into environmental protection as one of the most significant segments, the following criteria should be analyzed:

- Income from fees and taxes total;

- The structure of income by type of fees and taxes;

- The structure of income by beneficiaries (authorities that collect fees) and beneficiaries' levels (republic/province/local governments).

In addition to the previous analysis, it is necessary to differentiate the sources of funds earmarked for environmental protection (budget, own funds, donations, credits, etc.).

The document "Regulations on the National List of Environmental Indicators", contains indicators based on which the financing of environment should be monitored (Official Gazette of the Republic of Serbia, No. 37, 2011). It is stated in the document that investment and current environmental protection expenses are all the expenses the purpose of which is to prevent, remove or mitigate adverse effects on environment (excluding investment expenses and depreciation).

Table 1: Total annual investment into Programme implementation (including indirect expenses) per sub-sectors from 2013-2019 (in mil. EUR) (Belgrade Chamber of Commerce, 2010)

\begin{tabular}{|l|l|l|l|l|l|l|l|}
\hline Elements & $\mathbf{2 0 1 3}$ & $\mathbf{2 0 1 4}$ & $\mathbf{2 0 1 5}$ & $\mathbf{2 0 1 6}$ & $\mathbf{2 0 1 7}$ & $\mathbf{2 0 1 8}$ & $\mathbf{2 0 1 9}$ \\
\hline Waste & 70 & 138 & 128 & 133 & 139 & 144 & 150 \\
\hline Power industry & 47 & 51 & 141 & 192 & 243 & 227 & 244 \\
\hline Mining industry & 10 & 12 & 3 & 2 & 2 & 2 & 2 \\
\hline Industry & 20 & 15 & 18 & 21 & 25 & 28 & 31 \\
\hline Chemicals & 6 & 8 & 5 & 5 & 5 & 5 & 5 \\
\hline Transport & 12 & 12 & 68 & 79 & 94 & 107 & 127 \\
\hline Agriculture & 15 & 15 & 11 & 12 & 13 & 15 & 16 \\
\hline Land & 2 & 2 & 3 & 3 & 3 & 3 & 3 \\
\hline Air & 3 & 3 & 3 & 3 & 3 & 3 & 3 \\
\hline Water & 60 & 80 & 108 & 115 & 121 & 127 & 134 \\
\hline Nature & 1 & 4 & 3 & 3 & 3 & 4 & 4 \\
\hline Noise & 0,9 & 0,9 & 1 & 2 & 3 & 4 & 5 \\
\hline Radiation & 1 & 3 & 18 & 18 & 18 & 1 & 1 \\
\hline Total & $\mathbf{2 4 7 , 9}$ & $\mathbf{3 4 3 , 9}$ & $\mathbf{5 1 0}$ & $\mathbf{5 8 8}$ & $\mathbf{6 7 2}$ & $\mathbf{6 7 0}$ & $\mathbf{7 2 5}$ \\
\hline
\end{tabular}


There is still no precise record keeping in Serbia in respect of investment in environmental protection per various aspects. Table 1 contains projections of future investment in the period 2013-2019, which make investment and operating expenses. The programme includes activities directly related to the improvement of environment, as well as activities of sectors that improve the environment although the environmental protection is not their main purpose (transport infrastructure, drinking water treatment).

A report on the condition of the environment which is created annually in Serbia and approved by the Government of the Republic of Serbia is an important tool in planning environmental policy and strategic documents of the energy sector and other sectors (The Ministry of Energy, Development and Environmental Protection, 2012).

Serbia has made a significant progress in the financing of energy efficiency, which is driven by increased regulation in this area and activities to encourage a socially responsible behaviour. It is important to note that more attention should be paid to identifying sophisticated financial models for optimizing investments in renewable energy in order to adequately estimate performance of such projects, and so that the risk should be reduced to the lowest possible level. In addition, our state has to take a more active role in finding support mechanisms for investment in the renewable energy sector where a wide range of instruments are available such as tax breaks, guaranteed purchase prices of electricity, government guarantees, direct subsidies, long-term dedicated contracts and more. Lack of capital remains a major obstacle for the implementation of energy efficiency projects, particularly in developing countries, and strong cooperation between the public and private sectors is needed with a focus on public-private partnership which should contribute to reducing environmental risks for the company and to increasing innovation in the field of energy efficiency. Stošić, Knežević, Milutinović \& Lakićević, (2012, p.313.) point out that "eco-innovation can be treated as a compromise for a potential solution to this problem".

In addition to the direct funding from the municipal budget, municipal bonds or loans can also be applied to provide additional funding that cannot be collected from fees for services with a reasonable loan period.

In cooperation with relevant ministries and agencies, the Government should establish an energy efficiency fund that will finance measures for improvement of energy efficiency in industry and households, introduce energy consumption standards for construction of new and reconstruction of the existing buildings and introduce programmes for financing to promote insulation measures in residential and public buildings (eg., more favourable loans and tax relief) and connection of flats and buildings to the district heating or gas network.

Business banks are among the most important sources of project financing. Project financing plays an important role in their business, since in the conditions of intense competition, the survival of banks in the market is determined by the amount and quality of investment and investment return, and the revenue at risk. A number of banks in Serbia currently grant consumer loans for purchase of electrical devices and household appliances with energy rating label which shows the energy efficiency class and the average power consumption when using the devices and appliances. Financing of such projects has a positive impact on energy savings and energy efficiency.

In the context of new business and social environment, insurance companies may also be important actors in the financing of environmental protection. For example, through a set of activities, the Dunav Insurance Company shows its determination to establish a system that would lead to sustainable development, through establishing a balance between corporate social responsibility and accountability for successful business operations of the company. Namely, insurance companies can now be positioned in the way to affect environment by choosing how to invest their available funds. In investing in projects that contribute to environmental protection, directly or indirectly, especially in terms of construction of new facilities and plants of high energy efficiency that preferably use renewable energy, the primary goal is not to benefit from the operations of a certain plant or system that contribute to environmental protection, but the fact that constructed buildings require certain insurance coverage.

Knežević (2011) emphasizes that by selecting and applying appropriate accounting policies management can significantly affect an efficient management of the environment at the level of the business system in a way that the accounting policy would incorporate generating the ecological reports from a financial point of view in terms of defining 1) financial indicators to measure the economic and environmental effects, 2) identifying the need for accounting-standards of environmental protection, identifying the information necessary 
for assessing the environmental costs (Knežević, 2011). In this context, it is important to bear in mind the importance of monitoring costs on the basis of use of company cars, and thus exploring the possibilities for costs rationalization and use of public transport for performing business activities in the enterprise, where this is acceptable as an option.

\section{Conclusion}

All professionals from global energy sector realize the current necessity for energy transition. The current energy system needs to be replaced by another system that enables the provision of: (1) the long-term availability of energy, in support of economic growth necessitated by demographic growth, (2) required increase in living standards and taking into consideration things not included in current energy services and (3) safe procurement of energy sources which ensures the removal of geopolitical tensions that might rise.

Degradation of environment progresses at an unprecedented pace. The human impact on environment transformed the structure of the ecosystem of the planet in the second half of the $20^{\text {th }}$ century much faster than in any epoch in the world history, so we are today facing extreme environmental challenges worldwide. A pro-active approach of international financial institutions in financing environmental protection projects is expected. The role of the banks in financing eco-friendly projects is especially important since they are expected to provide special financial support to environmental protection, thus a special place in the field of social responsibility. In addition to banks, various funds that approve grants participate in the financing of eco-friendly projects.

Capital markets will certainly have a significant role in mobilising private capital for financing procedures of climate change mitigation and adjustment projects (Jančetović, Cvijić, p. 17). However, in order to raise the funds required to achieve a significant effect in the struggle against climate change, investment products must be designed to appeal to investors who have substantial funds. Capital markets are important sources of allocation of resources to projects that support solutions to problems caused by climate change, but employment of this capital may be risky, especially in times of crisis in financial markets. The World bank Green bonds support the financing of energy efficiency projects.

Investment in science can also improve the quality of the environment. The lack of a single national database on investment in environmental protection and non-harmonised methodology, in particular, are the critical research points of this paper and affect the comparability of data for analysis. The Environmental Protection Agency is responsible for collection of data on financing of environmental protection.

During the research it was noted that Serbian companies are not required to report to the state authorities the investments related to environmental protection, so increasing energy efficiency, on the one hand, and the lack of sufficient incentives for industry and energy sector to reduce pollution, on the other hand, both make it difficult to increase investments in energy efficiency and renewable energy.

It is necessary that modalities of financing energy efficiency projects should be paid special attention in the academic circles. The banks and insurance companies are also expected to promote projects granting greater responsibility for environment, and recognizing the importance of investing in renewable energy and recycling. Implementation of measures for reducing energy consumption and increasing energy efficiency has positive effects in terms of decrease in production costs and increase in competitiveness.

The Energy Efficiency Agency and regional energy efficiency centres in this country should intensify their campaigns to raise awareness and build capacity in terms of energy efficiency measures that should indicate the economic and environmental benefits from reduced fuel consumption.

The necessity to further invest in the field of environmental protection is obvious. The current financing sources of environmental protection in the Republic of Serbia are, first of all, the budget of the Republic of Serbia and income from fees and taxes. A significant source of energy efficiency funding in this country comes from from financial institutions and funds, as well as the capital of the companies.

The conclusion is that all sectors have to unite their efforts - public, private sector, and countries mutually, since it is a mutual responsibility. Spreading useful information on energy efficiency measures has a positive impact on investors in such projects, private and public organisations and domestic and international funds. Promotion of the importance of energy efficiency (rational energy consumption and greater usage of renewable energy) contributes to the development of corporate social responsibility in the field of energy consumption. 


\section{REFERENCES}

[1] Barbut, M. (2010). Investing in the Environmental Forefront, Public Private Partnership. Global Environment Facility. Washington DC, USA. Retrieved from https://www.thegef.org/gef/sites/thegef.org/files/publication/PPP\%20english\%20pub\%20web\%20927-07.pdf

[2] Belgrade Chamber of Commerce. (2010). National environmental protection program. Retrieved from http://www.kombeg.org.rs/Slike/CeTranIRazvojTehnologija/2010Mart/Nacionalni\%20program.pdf

[3] Carbon Markets. (2010). Ecosystem Marketplace, Bloomberg New Energy Finance. Global Banking \& Markets, Bloomberg 2010. Retrieved from www.bnef.com

[4] Chiginsky, A. L. (2010). Investing in low carbon development, The environmentalist 2010. Retrieved from http://treasury.worldbank.org/cmd/pdf/InvestinginLowCarbon.pdf

[5] Coretchi, I. (2009). SE4F Energy Efficiency Fund - EBRD invests in Southeast Europe Energy Efficiency Fund. Retrieved from http://www.ebrd.com/news/2009/ebrd-invests-in-southeast-europe-energy-efficiency-fund.html

[6] EBRD. (2009).Green for Growth Fund, Southeast Europe. Retrieved from http://www.ebrd.com/work-with-us/projects/psd/green-for-growth-fund-southeast-europe-f-see-en-efffd.html

[7] Energy Information Administration (US Department of energy). (2006). International Energy Outlook 2006. Retrieved from http://www.economicswebinstitute.org/essays/energy2006.pdf

[8] Garcia, B. \& Roberts, E. (2011). Carbon Finance: News \& Analysis of Market solution to climate change, 18. Retrieved from http://environment.yale.edu/publication-series/5767.html

[9] Green for Growth Fund. (2015). Investment in Renewable Energy Projects. Retrieved http://www.ggf.lu/investees-clients/a-renewable-energy-project-developer/investments-in-renewableenergy-projects/

[10] International Energy Agency. (2006). World Energy Outlook 2006. Retrieved from https://www.iea.org/publications/freepublications/publication/weo2006.pdf

[11] International Finance Corporation. (2015). Retrieved from http://www.ifc.org/wps/wcm/connect/CORP_EXT_Content/IFC_External_Corporate_Site/About+IFC/I FC+History/

[12] Jančetović M. \& Cvijić J. (2012). Financing projects in function of environment protection. XIII International Scientific and Professional Conference „Accounting and Management“, Croatian Accountant, Zagreb, Croatia, June 2012., published in Conference Proceedings, Zagreb, 12-18.

[13] Jednak, S., Kragulj, D., Bulajić, M., \& Pittman, R. (2009). Electricity reform in Serbia, Utilites Policy, 17,125-133. doi:10.1016/j.jup.2008.02.002

[14] Kelly, L. \& Jordan, J. (2004). The Prototype Carbon Fund, Addressing Challenges of Globalization: An Independent Evaluation of the World Bank's Approach to Global Programs, The World Bank Washington, D.C. Retrieved from http://ieg.worldbank.org/Data/reports/gppp carbon wp.pdf

[15] Knežević S. (2011). Accounting for environmental protection. Accounting, 9-10, Serbian Association of Accountants and Auditors, Belgrade, 48-56.

[16] Knežević, S., Joksimović, I. \& Bilić, M. (2012, March). Financing Environmental Projects. Paper presented at thelnternational Conference on Organizational Science, Development - Quality, Inovation, Future, University of Maribor, Faculty of Organizational Sciences, Portorož, Slovenia. Retrieved from http://www.fov.si/conference/archive/2012/files/ProgramPortoroz2012.pdf

[17] Knežević, S., Marković, M. \& Počuča, M. (2012). Approach PPP in financing energy efficiency projects - financial and legal framework. European Union Legislation, thematic issue of "Environmental Protection", 149-167.

[18] Knežević, S., Marković, M. \& Stanković, A. (2013, November). Sustainable investments with focus on the environment, IX Symposium of Business and Science SPIN '13, New industrialization, reengineering and sustainability, 2013, Belgrade, Serbia, University of Belgrade, Faculty of Organizational Sciences, Operations Management Center Chamber of Commerce and Industry of Serbia, 43-52.

[19] Kreiß, C. \& Roos, D. (2009). Southeast Europe Energy Efficiency Fund (SE4F). Retrieved from http://www.energy-community.org/pls/portal/docs/410181.PDF

[20] Official Gazette of the Republic of Serbia, No. 12/2010. (2010). National environmental protection program. Decision on determination the National Programme of Environmental Protection.. Retrieved from http://www.ekourb.vojvodina.gov.rs/sites/default/files/ODLUKA\%20Nacionalni\%20program_0.doc 
[21] Official Gazette of the Republic of Serbia, No. 37/2011. (2011). Regulations on the list of environmental indicators. Retrieved from http://www.kombeg.org.rs/Slike/CeTranIRazvojTehnologija/2011/2011\%20Decembar/Nacionalna\%20lista\%20indikatora.pdf

[22] Official Gazette of the Republic of Serbia, No. 135/2004, 36/2009, 36/2009 - other law, 72/2009 - other law and 43/2011 - decision US). (2011). The Law on Environmental Protection. Retrieved from http://www.paragraf.rs/propisi/zakon_o_zastiti_zivotne_sredine.html

[23] Official Gazette of the Republic of Serbia, No. 80/11. (2011). National Environmental Approximation Strategy for the Republic of Serbia. Retrieved from http://www.misp-serbia.rs/wp-content/uploads/2010/05/EAS-Strategija-ENG-FINAL.pdf

[24] Official Gazette of the Republic of Serbia, No. 88/2011. (2011). The Law on public-private partnerships and concessions. Retrieved from http://www.paragraf.rs/propisi/zakon_o_javno_privatnom_partnerstvu_i_koncesijama.html

[25] Petrović, N., Išljamović, S. \& Jeremić, V. (2010). Zero waste as a new concept for sustainable waste management. Management-Journal for Theory and Practice, 57, 39-46.

[26] Petrović, N., Slović, D. \& Ćirović, M. (2012). Environmental Performance Indicators as Guidelines Towards Sustainability. Management-Journal for Theory and Practice, 64, 5-14. doi: 10.7595/management.fon.2012.0026

[27] Stošić, B., Knežević, S., Milutinović, R. \& Lakićević, A. (2012). The key elements of management ecoinnovation. Economic aspects of environmental policy, (pp. 313-329). Belgrade, Serbia: Institute of Economic Sciences, Belgrade Banking Academy-Faculty for Banking, Insurance and Finance

[28] The Agency for Regional Development, Croatia \&The Delegation of the European Union to the Republic of Serbia. (May, 2007). Instrument for Pre-Accession Assistance (IPA), Cross-Border Programme - Croatia - Serbia, 2007-2013. Retrieved from http://www.croatia-serbia.com/index.php?option=com_content\&view=article\&id=16\&ltemid = 19

[29] The Climate Investment Funds (CIF). (2015). MDB ROLE. Retrieved from http://www.climateinvestmentfunds.org/cif/node/48

[30] The Ministry of Energy, Development and Environmental Protection, Republic of Serbia. (2012). The report on the environmental situation in the Republic of Serbia for 2011. The Agency for Environmental Protection. Retrieved from http://www.sepa.gov.rs/download/lzvestaj_2011.pdf

[31] The World Bank. (2009). Green Bond. Retrieved from http://treasury.worldbank.org/cmd/htm/WorldBankGreenBonds.html

[32] The World Bank. (2011). Green Bond. THIRD ANNUAL INVESTOR UPDATE 2011. Retrieved from http://treasury.worldbank.org/cmd/pdf/WorldBankGreenBondNewsletter2011.pdf

[33] The World Bank. (2014). Green Bond. FACT SHEET. Retrieved from http://treasury.worldbank.org/cmd/pdf/WorldBank_GreenBondFactsheet.pdf

[34] WCED - World Commission on Environment and Development. (1987). Report of the World Commission on Environment and Development: Our Common Future. Oxford University Press, Oxford.

[35] WeBSEDFF. (2015). Retrieved from http://www.websedff.com/index.php?id=25\&PHPSESSID=bedf0583d11674d26e198d8fd1ce82c0

Receieved: February 2015. Accepted: June 2015 


\section{$1 / 1 / 1 / 1 / 1 / 1 / 1 / 1 / 1 / 1 / 1 / 1 / 1 / 1 / 1 /$ abouthe eathor}

\section{Milan Počuča \\ University Business Academy in Novi Sad, Faculty of Law}

Milan Počuča was born in 1962 in Gospic, Croatia. He graduated from the Faculty of Law, University of Zagreb in 1986. He completed his master and doctoral studies at the Faculty of Law, University Business Academy Novi Sad. He has published more than 90

scientific papers in international and national journals, and also in international and nationalconferences and scientific conventions. He is a member of the Scientific

Committee in several international scientific conferences and national scientific and professional conventions. He is currently employed at the Faculty of Law, University Business Academy Novi Sad as associate professor, where he is also a Vice Dean for science, quality and development.

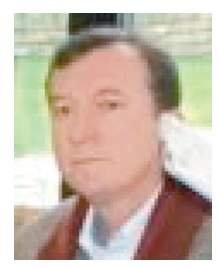

Rajko Tepavac

University Business Academy in Novi Sad, Faculty of Economy and Engineering management

Ph. D. Rajko Tepavac (1957) graduated from the Faculty of Economics, University ofBelgrade and acquired a title of authorized broker - dealer in 2000. He earned his

Master's Degree in Legal and Economic Sciences in 2006, at the Academy of Commerce in Novi Sad, and in 2008 he defended his doctoral dissertation and earned his $\mathrm{PhD}$ in Economics. He is currently engaged as a member of the Executive Board of

the "Dunav Insurance" Company, where he is in charge of corporate governance, strategy and product development, at the University Business Academy,

Fimek, in Novi Sad, in his capacity as assistant professor, where he is a lecturer at the Insurance study course. He is the author of numerous books and papers, with special emphasis on diverse areas of security, regional development perspective, the insurance industry and legal regulation of these.

\section{Jana Cvijic \\ Belgrade Business School}

Jana Cvijic, assistant professor at the Belgrade Business School in Belgrade for the study subjects Accounting and Managerial Accounting.

She graduated from the Faculty of Trade and Banking "Janicije and Danica Karic" in

Belgrade.She defended her Master thesis "Contemporary global financial crisis" in

2011, at the Faculty of Economics and Engineering Management, Department of

Business Economics and Finance, at the University Business Academy in Novi Sad, obtaining a title of Master of Science (MSc). Currently, she is attending her third year of

Doctoral $(\mathrm{PhD})$ studies at the Faculty of Economics and Engineering Management, Department of Business Economics, at the University Business Academy in Novi Sad.

Aleksandra Mitrović University of Kragujevac, Faculty of Hotel Management and Tourism aleksandra.stankovic@kg.ac.rs

Aleksandra Mitrović works as a teaching assistant at the Faculty of Hotel Management and Tourism in Vrnjačka Banja, University of Kragujevac. She completed her Bachelor

Studies in Accounting and Corporate Finance as well as her Master studies at the Faculty of Economicsin Kragujevac. The fields of her scientific and professional interests
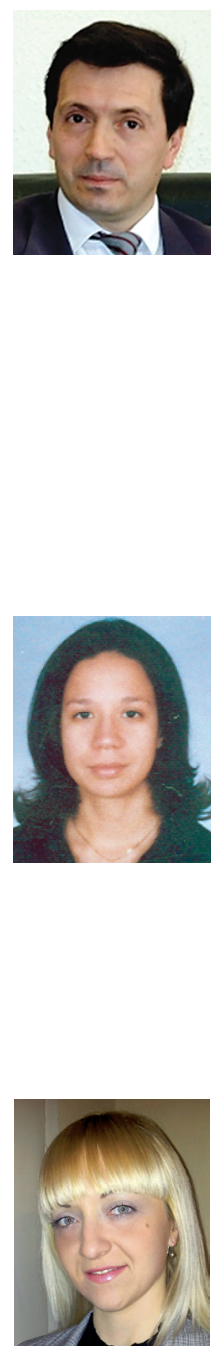
are related to Accounting and Finance. 